\title{
Impact Of E-Commerce On The Purchasing Power Of Community In Retail Companies In Denpasar
}

\author{
Ni Luh Kardini ${ }^{1}$, I Dewa Nyoman Usadha ${ }^{2}$ \\ \{kardini.mahayoga@gmail.com¹, mahausadha888@gmail.com $\left.{ }^{2}\right\}$ \\ Faculty of Economics, Mahendradatta University, Bali ${ }^{1,2}$
}

\begin{abstract}
This year, quite a number of retailers have collapsed. The lack of purchasing power in the retail industry, one of which is the large number of e-commerce that pampers buyers with ease. The impact of e-commerce on people's purchasing power on retail companies in Denpasar, the sampel used issaturation with respondents 100 people. The measurements used the Likert scale and the analysis was using a multi linear regression statistical method by conducting a $\mathrm{T}$ test and a $\mathrm{F}$ test at a significant to determine the magnitude of the total influence and the variables that provided the dominant effect. Based on analysis SPSS that tastes, prices and income levels affect people's purchasing power significantly. The amount of influence is based on the value of the determination coefficient $(\mathrm{r} 2)=0.643$ which means that $64.3 \%$ of tastes, prices and income levels, while e-commerce affects $9.5 \%$, the remaining $26.2 \%$ is influenced by other variables.
\end{abstract}

Keywords: Retail, Community Purchasing Power, Ecommerce

\section{Introduction}

Based on data from the Central Statistics Agency (BPS), the Indonesian economy in the first quarter of 2019 only grew 5.07 percent compared to the same period last year or grew negatively by 0.52 percent compared to the previous quarter. One of the causes of the economy's slow growth is the slowdown in household consumption growth. In the first quarter of this year, consumption growth was recorded at 5.01 percent on an annual basis. Although better than the same period last year, consumption slowed slightly from the fourth quarter of last year which reached 5.08 percent.

As the biggest contribution to the economy, household consumption is one of the references to measure the economy as a whole. The trend of consumption growth is always in line with the pace of the economy. When consumption slows down, it will almost certainly have an effect on the aggregate economic growth. For example, data on gross domestic product (GDP) in the fourth quarter of 2017, the contribution of household consumption is still dominant, namely 56.13 percent. However, this contribution decreased from the fourth quarter of 2016 which was 56.56 percent. The decline occurred due to the impact of household consumption which only grew 4.97 percent (yearon-year) or decreased in comparison fourth quarter 2016 which amounted to 4.99 percent. Slowing growth in household consumption has an impact on people's purchasing power.

The problem of purchasing power is strongly influenced by people's income as expressed. The growth of the online industry has also been linked to the decline in conventional retail stores. 
Purchasing power is the ability of individuals and organizations to buy and use goods and services. In measuring purchasing power, the factors that influence purchasing power according to Basu Swastha and Irawan (2003:403) [1] are income, taste, and price factors. Income is money that a person receives in the form of wages, rent, interest or profit. Taste is a person's willingness or desire to consume and use goods or services. Price is the amount of money that is charged on a certain product, the price in sales is very influential on individuals and groups in making purchases. The pricing strategy is very significant in giving value to consumers and product image (tastes), as well as consumer decisions to buy. Pricing is also related to income and also influences supply because of consumers' appetite or willingness to consume again.

According to Basu Swastha and Irawan (2003:403) [1], the sales value is the number of sales received or obtained in a certain period, thus the sales value is the achievement or realization of sales of the expected target, the fact of the sale illustrates the purpose of selling a product or service. For most goods, an increase in income will cause an increase in demand. If the elasticity value of changes in income to changes in demand, the level of elasticity is positive, then the goods are called normal goods. Elasticity is a measure of the degree of sensitivity to change in quantity demand for goods to changes in price. In addition, if there are goods that have decreased in the amount purchased, if the income increases, it means that their elasticity is negative and these goods are called inferior goods. This elasticity is known as income elasticity.

The decrease in income is felt by low-income people, especially in urban areas, so that it will directly affect people's purchasing power, there is a decrease in people's purchasing power as well as the impact of limited employment opportunities, so even if people do not enter open unemployment, they are thrown into the informal sector. This sector certainly does not generate sufficient income. So that if the income is not sufficient, the goods that can be purchased are very limited. This condition is one of the indicators of decreasing purchasing power. Modern market in retail sector little by little being abandoned, switching to online buying and selling is alleged to have contributed significantly to the purchasing power of the sluggish people with the retail industry. Various reasons such as practicality, more choices, no need to bargain and providing lower prices are the main attraction for choosing online shopping. What's more, the security and level of consumer confidence in online shops is getting higher and higher. This makes buying and selling online increasingly popular with the community, especially young people. Some retail in Denpasar include Matahari Duta Plaza, Robinson, Mall Ramayana, Level 21 Mall, Plaza Renon, Mall Bali galleria, Beachwalk Shopping Center, Seminyak Village, Lippo Plaza Sunset, Bali Collection, Discovery Shopping Mall, Park 23, Matahari Kuta Square.

\section{Methods}

It aims to know the factors that affect people's purchasing power in retail companies in Denpasar and the impact of the presence of e-commerce. This research implements quantitative research methods with a descriptive data analysis approach. According to Arikunto (2006) [2], quantitative research is a study that uses many numbers, ranging from data collection, data interpretation, and the emergence of results. Meanwhile, according to Masyhuri and Zainuddin (2008) [3], quantitative research is research that does not focus on data depth, quantitative research 
is not very focused on data depth, which is important is to record as much data from a broad population.

This research aims to test the hypothesis that utilizes the causal relationship of several variables, namely the factors that influence the analysis that affects people's purchasing power in retail companies in Denpasar with the impact of the influx of e-commerce. Taste, price level income, price, and e-commerce this affects the purchasing power of the community at retail companies in Denpasar.

The population in this study was e-commerce users and consumers at retail companies in Denpasar. The sample is part of the number and characteristics of the population (Sugiyono,2013) [4]. This study used an accuracy rate $(\alpha)$ of $5 \%$ and a confidence level of $95 \%$ so that the value obtained $\mathrm{Z}=1.96$. Acceptable error rate of $10 \%(0.1)$. Then, the probability of the questionnaire is true $\mathrm{q}$ (received) or false $\mathrm{p}$ (rejected) of $50 \%(0.5)$ each. Therefore, the sample used to represent the population is as many as 100 respondents. The sampling technique used in this study is purposive sampling. Purposive sampling is the determination of a sample with certain considerations, for example the person is considered to have knowledge of what we expect, so it will make it easier for researchers to explore the objects or social situations studied (Sugiyono,2014) [5].

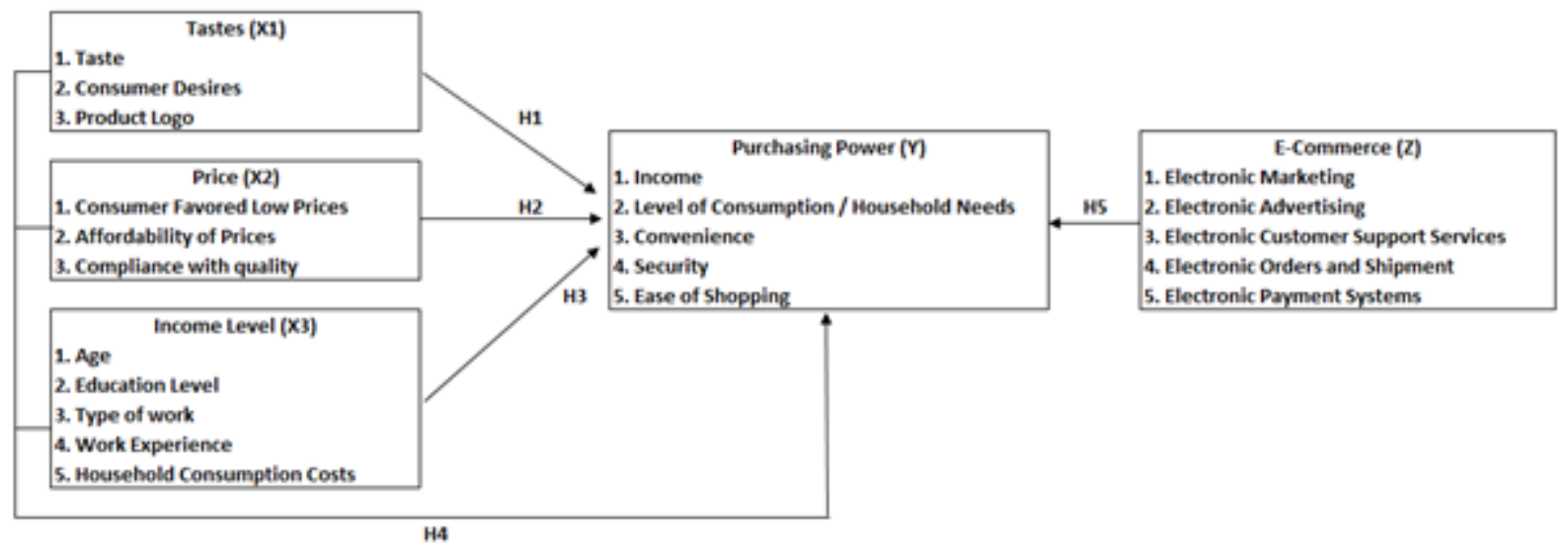

Fig.1. Framework

\section{$3 \quad$ Results and Discussions}

Retail is an activity of marketing products, both goods and services, which is carried out in retail or in direct units to end consumers for household or personal use, not for resale. Retail sellers are also called retailers / retailers. Various reasons such as practical, more choice, no need to bargain and provide lower prices are an attraction for choosing to shop online. What's more, the security and level of consumer confidence in online shops is getting higher and higher. This makes buying and 
selling online increasingly popular with the community, especially young people. Some retail in Denpasar include Matahari Duta Plaza, Robinson, Mall Ramayana, Level 21 Mall, Plaza Renon, Mall Bali galleria, Beachwalk Shopping Center, Seminyak Village, Lippo Plaza Sunset, Bali Collection, Discovery Shopping Mall, Park 23, Matahari Kuta Square .

The presence of e-commerce is the purchase and sale of goods, services and information using consumer services through computer networks that cover the internet and internal transactions within an organization. So that e-commerce includes all electronic transactions. The benefits of ecommerce include convenience, data speed, access 24 hours a day, efficiency, alternative space and limitless choices. E-commerce in the era of technology and the internet is an essential requirement in the world of business and business as a support for market development, increasing efficiency, reducing costs, and providing wider access for corporate customers in making purchasing decisions.

\subsection{The influence of tastes on people's purchasing power on retail companies in Denpasar}

Based on the calculations performed, the $t$ value of the count $=5,043$ compared to the table $t$ $=1.6$ and the significance level of 0.000 is smaller than 0.05 which means that variable tastes exert a positive and significant influence on people's purchasing power in retail companies. This shows that people still love direct shopping at retail companies.

\subsection{The effect of price on people's purchasing power on retail companies in Denpasar}

Based on the calculations performed, the calculated $t_{\text {value }}=1,973$ compared to table $t=1.6$ and significance level 0.051 is greater than 0.05 which means that the variable price is not significant to the purchasing power of the community, where it is proven that at a significant level $\alpha(0.05)$, so the price does not deterninate significantly to the purchasing power of the community. This shows that people are still not fixated on price size as a determinant in making shopping choices, adjusting their need for products.

3.3 The effect of income level on people's purchasing power on retail companies in Denpasar

Based on the calculations made, the calculated $t$ value $=5,393$ compared to the table $t=1.6$ and the significance level of 0.000 is smaller than 0.05 which means that the variable income level exerts a positive and significant influence on people's purchasing power in retail companies. This shows the amount of income received shows their ability to shop.

\subsection{Influence of tastes, price and income level on purchasing power in retail companies in Denpasar}

Based on the calculations made, it is obtained that $\mathrm{F}$ count $=45,988$ with a significant 0.000 , it turns out that the significant value of $\mathrm{F}$ is less than 0.05 . This means that in tastes (X1), price (X2) and the level of income (X3), statistically at the level of confidence $(\alpha)=5 \%$, have a significant/positive effect on purchasing power $(\mathrm{Y})$. This means that the simultaneous test shows that tastes, prices and income levels together have a significant determination on people's purchasing power.

\subsection{The effect of e-commerce on people's purchasing power at retail companies in Denpasar}


Based on the calculations carried out, the obtained $t$ value $t=9,547$ compared to $t$ table $=1.6$ and the significance level of 0.000 is less than 0.05 , which means that e-commerce has a positive and significant influence on people's purchasing power to provide alternative shopping options for the choice to shop at retail company. This shows that e-commerce has an influence on shopping choices.

This is in line with research conducted by Lili Rifki Yanti (2016) [6] showing that income level has an influence with the level of relationship being in the "strong" category on purchasing power. This is based on the result of the product moment correlation coefficient which is equal to 0.785 , then the contribution of income to purchasing power is $61.7 \%$ and the remaining $38.3 \%$ is influenced by other factors. It is proven that the level of income has a significant effect on purchasing power. The research conducted by Faisal, et al. (2020) [7] states that based on the results of the chi-square test using SPSS on the e-commerce variable obtained a chi-square value of 16,309 and a p-value of $0.001<0.05$, so there is an influence between e-commerce variables on purchasing interest in vegetable products in Banda Aceh City.

\section{Conclusion}

Based on the analysis that has been carried out to see the impact of e-commerce on people's purchasing power at retail companies in Denpasar, it can be concluded that:

1. Tastes has a positive and significant effect on people's purchasing power.

2. Price does not have a positive and not significant effect on people's purchasing power.

3. Income levels have a positive and significant effect on people's purchasing power.

4. Tastes, price, income level together have a positive and significant impact on people's purchasing power. Analysis of several determinations resulted in a determination coefficient of $64.30 \%$

5. E-commerce has a positive and significant effect on people's purchasing power.

\section{References}

[1] Basu Swastha dan Irawan: Manajemen Pemasaran Modern. (Edisi kedua). Cetakan ke sebelas. Yogyakarta: Liberty Offset, (2003).

[2] Arikunto: Prosedur Penelitian Suatu Pendekatan Praktek. Jakarta: PT. Rineka Cipta, (2006).

[3] Masyhuri and Zainuddin, M.: Metodologi Penelitian Sosial Ekonomi, Teori dan Aplikasi. Bandung: Penerbit Alfabeta, (2008).

[4] Sugiyono: Metodelogi Penelitian Kuantitatif, Kualitatif Dan R\&D. Bandung: Alfabeta, (2013). 
[5] Sugiyono: Metode Penelitian Pendidikan Pendekatan Kuantitatif, Kualitatif,dan R\&D. Bandung: Alfabeta, (2014).

[6] Lili Rifki Yanti: Pengaruh Pendapatan Mahasiswi Terhadap Daya Beli Mahasiswi Iain Palangka Raya Dalam Membeli Pakaian Berhijab Secara Online Di Media Sosial, Institut Agama Islam Negeri Palangka Raya, (2016).

[7] Faisal, et al.: Pengaruh E-Commerce Terhadap Minat Beli Konsumen Pada Produk Sayuran Di Kota Banda Aceh. Jurnal Ilmiah Mahasiswa Pertanian Vol 5, No 4. (2020) 